sleep apnea. American Journal Respiratory Critical Care Medicine, 179(4):320.

3. Zaghi S Certal VF, Riaz M, et al (2015). Hypoglossal nerve stimulation in the treatment of obstructive sleep apnea: A systematic review and meta-analysis. Laryngoscope, 125, 1254-1264.

4. Blumen $M$, Bequignon $E$, Chabolle $F$ (2017). Drug-induced sleep endoscopy: A new gold standard for evaluating OSAS? Part I: Technique. Eur Ann Otorhinolaryngol Head Neck Dis. 2017 Apr;134(2):101-107

5. Dempsey JA, Veasey SC, Morgan BJ, O'Donnel CP (2010). Pathophysiology of sleep apnea. Physiol Rev. 2010;90:47

6. Salam O. Salman, 2019 Modern Management of
Obstructive Sleep Apnea.

7. Kushida C Li KK, Powell NB, et al (2000). Obstructive sleep apnea syndrome: a comparison between Far-East Asian and white men. Laryngoscope, 110, 1689-1693.

8. Palta M Young T, Dempsey J, et al (2009). Burden of sleep apnea: rationale, design, and major findings of the Wisconsin Sleep Cohort study. Wisconsin Medical Journal, 108(5), 246-249

9. Vanderveken OM, Maurer JT, Hohenhorst W, et al (2013) Evaluation of drug-induced sleep endoscopy as a patient selection tool for implanted upper airway stimulation for obstructive sleep apnea. J Clin Sleep Med. 2013;9(5):433-438.

\title{
KHẢO SÁT NỒNG Độ C - PEPTIDE VÀ MỐI LIÊN QUAN VỚI BIẾN CHỨNG VI MẠCH Ở BỂNH NHÂN ĐÁI THÁO ĐƯỜNG TYPE 2
}

\section{TÓM TẮT}

C - Peptide là một polypeptide được tiết racùng lúc và với môt lượng tương đương với insulintừ tế bào beta tụy. Việc xét nghiệm nồng độ $C$ - Peptide lúc đói có thể cho chúng ta biết được lượng insulin nội sinh ở bênh nhân đái tháo đường... Mục tiêu: Khảo sát nồng độ $C$ - Peptide và mối liên quan với biến chứng võng mạc mắt và albumin niệu ở bệnh nhân đái tháo đường type 2. Đối tượng và phương pháp: nghiên cứu mô tả cắt ngang 87 bệnh nhân đái tháo đường type 2 khám tại Bệnh viện Bạch Mai từ tháng 01/2021 đến 8/2021. Kết quả: Nồng độ $C$ - Peptide lúc đói trung bình trên nhóm bệnh nhân nghiên cứu là: $0,83 \pm 0,35$ $\mathrm{nmol} / \mathrm{l}$. Nồng độ $\mathrm{C}$ - Peptide lúc đói có mối tương quan nghịch biến ở mức độ vừa phải với nồng độ albumin niệu $(r=-0,352, p=0,001$, spearman test). Nồng độ $C-$ Peptide lúc đói trên nhóm bệnh nhân có microalbumin niệu: $0,72 \pm 0,34 \mathrm{nmol} / \mathrm{l}$, nhóm không có microalbumin niệu: $0,88 \pm 0,35 \mathrm{nmol} / \mathrm{l}$, sự khác biệt có ý nghĩa thống kê với $p=0,047$. Nồng độ $C-$ Peptide lúc đói trên nhóm bệnh nhân có biển chứng võng mạc mắt: $0,72 \pm 0,33 \mathrm{nmol} / \mathrm{l}$, nhóm không có biến chứng võng mac mắt: $0,9 \pm 0,36 \mathrm{nmol} / \mathrm{l}$, sự khác biệt có ý nghĩa thổng kê với $p=0,041$. Kết luận: Nồng đô $C$ - Peptide lúc đói có mối tương quan nghich biến mức độ vừa phải với nồng độ albumin niệu. Nồng độ $C$ - Peptide lúc đói giảm có ý nghĩa thống kê trên nhóm bệnh nhân có biển chứng võng mạc mắt do đái tháo đường và nhóm bệnh nhân có tổn thương microalbumin niệu. Từ khóa: $\mathrm{C}-$ Peptide, biến chứng võng mạc mắt, microalbumin niệu.

\section{${ }^{1}$ Trường Đại Học Y Hà Nội}

${ }^{2}$ Bênh viên Bach Mai

Chịu trách nhiệm chính: Trần Mai Nguyên

Email: nguyentran.hmu0809@gmail.com

Ngày nhận bài: 21.6.2021

Ngày phản biện khoa học: 16.8.2021

Ngày duyệt bài: 25.8.2021
Trần Mai Nguyên ${ }^{1}$, Đỗ Trung Quân ${ }^{1,2}$

\section{SUMMARY \\ FASTING SERUM C - PEPTIDE IN TYPE 2 DIABETIC PATIENTS AND THE ASSOCIATION WITH MICROVASCULAR COMPLICATIONS}

C-Peptide is a polypeptide secreted simultaneously and in equimolar amounts with insulin from pancreatic beta cells. By measuring fasting serum C - Peptide, we can evaluate endogenous insulin reserve in diabetic patients. Aims: To survey on fasting serum $\mathrm{C}$ - Peptide and to comment on the association between fasting serum C - Peptide and diabetic retinopathy and urine albumin. Subjects and methods: crosssectional description study of 87 patients with a diagnosis of type 2 diabetes at Bach Mai Hospital from January 2021 to August 2021. Results: In this study, the mean value of fasting serum $C$ - Peptide is $0,83 \pm$ $0,35 \mathrm{nmol} / \mathrm{l}$. Negative correlation was seen between fasting serum $\mathrm{C}-$ Peptide and urine albumin level $(r=-$ $0,352, p=0,001$, spearman test). The mean values of fasting serum C-Peptide in patients with microalbuminuria and no microalbuminuriaare $0,72 \pm$ $0,34 \mathrm{nmol} / \mathrm{l}$ and $0,88 \pm 0,35 \mathrm{nmol} / \mathrm{l}$ respectively. Also in this study, the mean values of fasting serum $C$ Peptide in patients with diabetic retinopathy and no diabetic retinopathy are $0,72 \pm 0,33 \mathrm{nmol} / \mathrm{l}$ and $0,9 \pm$ $0,36 \mathrm{nmol} / \mathrm{l}$ respectively. Conclusion: The mean value of fasting serum $C$ - Peptide in this study is 0,83 $\pm 0,35 \mathrm{nmol} / \mathrm{l}$. The current study showed a significant correlation between fasting serum $\mathrm{C}$ - Peptide and urine albumin level. Fasting serum C - Peptide was significantly associated with diabetic retinopathy and microalbuminuria.

Keywords: Fasting serum C - Peptide , diabetic retinopathy, microalbuminuria.

\section{I. ĐĂT VẤN ĐỀ}

Đái tháo đường (ĐTÐ) hiện nay là một bệnh phổ biến và là mối quan tâm của tất cả các quốc gia trên thế giới bởi sự tăng lên nhanh chóng về 
số người mắc bênh cũng như các biến chứng nghiêm trọng của nó. Trong đó, các biến chứng trên hệ thống tim mạch đặc biệt là biến chứng liên quan đến vi mạch như bệnh võng mạc đái tháo đường (BVMĐTĐ) hay bệnh thận ĐTÐ chiếm phần lớn. Nguy cơ đe dọa do BVMĐTĐ và bệnh thận ĐTÐ là rất cao, làm ảnh hưởng đên kinh tế, tinh thần và chất lượng cuộc sông của người bênh. Việc phát hiện sớm các tổn thương mắt, thận trên bệnh nhần ĐTÐ có vai trò vô cùng quan trong. Microalbumin niệu (MAU) được coi là một yếu tố dự đoán biến chứng thận sớm ở bệnh nhân ĐTÐ. Chụp đáy mắt là một phương pháp phát hiện các tổn thương võng mạc ĐTĐ.

C - Peptide là một polypeptide gôm 31 acid amin được sản xuất từ tế bào beta tụy cùng một lúc và cùng một lượng với insulin từ sự phân hủy proinsulin. Do có thời gian bán hủy kéo dài hơn 4-5 lần, được bài tiết ở thận nguyên vẹn do vậy C - Peptide có khả năng đánh giá được chức năng của tế bào beta, tốt hơn insulin. Các biến chứng vi mạch trên bệnh nhân ĐTĐ type 2 thường có sự liên quan đến việc kiểm soát đường huyết không tốt. Thông qua $C$ - Peptide chúng ta có thể đánh giá được chức năng của tế bào beta tụy từ đó giúp mở ra hướng tiên lượng và điều trị mới liên quan đến biến chứng vi mạch trên bệnh nhân ĐTĐ type 2 . Trên thế giới, có nhiều nghiên cứu liên quan đến nồng độ $C$ Peptide và biến chứng vi mạch trên bệnh nhân ĐTĐ type 2 tuy nhiên ở Viêtt Nam, nghiển cứu về vấn đề này là chưa nhiều. Vì vậy chúng tôi tiến hành đề tài với mục tiêu "Khảo sát nồng độ $C$ Peptide và mối liên quan với biến chứng vi mạch trên bênh nhân đái tháo đường type 2".

\section{II. ĐỐI TƯỢNG VÀ PHƯƠNG PHÁP NGHIÊN CỨU}

1. Đối tượng nghiên cứu. Gồm 87 bệnh nhân được chẩn đoán đái tháo đường type 2 theo tiêu chuẩn của Tổ chức y tế thế giới (WHO) 2011 và Hiệp hội Đái tháo đường Hoa Kỳ (ADA) 2020. Loại trừ các trường hợp bệnh nhân dùng insulin hay thuốc sulfunylurea trong vòng 48 giờ và những bệnh nhân không đồng ý tham gia nghiên cứu.

*Thời gian nghiên cứu: từ tháng 1/2021 đến 8/2021.

*Địa điểm nghiên cứu: Khoa khám bệnh bênh viên Bach Mai.

\section{Phương pháp nghiên cứu}

*Thiêt kế nghiên cứu: Nghiên cứu mô tả cắt ngang, từ $1 / 2021$ đến $8 / 2021$

*Cỡ mâ̂u: Lây mẫu thuận tiện, toàn bộ bệnh nhân đái tháo đường type 2 đủ tiêu chuẩn trong thời gian nghiên cứu nói trên.
*Các chỉ tiêu nghiên cứu:

- Đặc điểm nhân trắc học: tuổi, giới, cân nặng, chiều cao.

- Đặc điểm cận lâm sàng:

o Nồng độ $C$ - Peptide lúc đói

- Microalbumin niệu (MAU): đánh giá qua mẫu nước tiểu ngẫu nhiên.

- Chụp đáy mắt: chụp hình cả hai đáy mắt không huỳnh quang.

- Phương pháp đánh giá:

- Chẩn đoán ĐTĐ typ 2 theo Hiệp hội Đái tháo đường Hoa Kỳ (ADA) 2020 và tiêu chuẩn của Tổ chức y tế thế giới (WHO) 2011.

- Tiêu chuẩn đánh giá tổn thương thận ĐTĐ. ${ }^{1}$

- Phân loại bệnh võng mạc mắt do ĐTÐ theo ETRDS (Early Treatment Diabetic Retinopathy Study).

- Chỉ số khối cơ thể (BMI): Theo tổ chức y tế thế giới (WHO) giành cho người châu Á.

*Xử lý và phân tích số liệu: các số liệu sau khi thu thập xử lý thống kê bằng phần mềm IBM SPSS Statistic 20.

*Đạo đức nghiên cứu: Đề tài đã được Hội đồng thông qua đề cươngTrường Đại học Y Hà Nội chấp thuận. Thông tin thu thập từ nghiên cứu được mã hóa, giữ kín và chỉ phục vụ cho mục tiêu nghiên cứu.

\section{KẾT QUẢ NGHIÊN CỨU}

\section{1. Đặc điểm chung của đối tượng nghiên} cứu

1.1. Đặc điểm về tuổi

Bảng 1. Phân bố tuổi của đôi tượng nghiên cứu $(n=87)$

\begin{tabular}{|c|c|c|c|}
\hline Phân bố tuối & $\mathbf{n}$ & $\mathbf{\%}$ & $\overline{x_{ \pm}} \mathbf{S D}$ \\
\hline Dưới 40 & 7 & 8,0 & $36,86 \pm 2,80$ \\
\hline $40-60$ & 58 & 66,7 & $51,79 \pm 5,77$ \\
\hline Trên 60 & 22 & 25,3 & $67,59 \pm 4,75$ \\
\hline Tống & 87 & 100 & $54,59 \pm 10,11$ \\
\hline
\end{tabular}

Nhận xét: Độ tuối trung bình của nhóm nghiên cứu là $54,59 \pm 10,11$. Bệnh nhân nhỏ tuổi nhất là 31 tuổi, bệnh nhân lớn tuổi nhất là 81 tuổi. Độ tuổi thường gặp nhất là từ $40-60$ tuổi (chiếm 66,7\%).

1.2 Đặc điểm về giới:

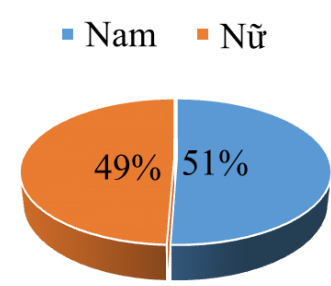

Biểu đồ 1. Phân bố đôi tướng theo giới

Nhận xét: Tỉ lệ nam: 50,6\%, nữ: 49,4\% như vậy tỉ lệ nam/nữ xấp xỉ 1:1. 
1.3 Phân bố đối tượng theo BMI

Bảng 2. phân bố đối tượng theo BMI $(n=87)$

\begin{tabular}{|c|c|c|}
\hline BMI & $\begin{array}{c}\text { Số BN } \\
\text { (n) }\end{array}$ & $\begin{array}{c}\text { Tỷ lệ } \\
\mathbf{( \% )}\end{array}$ \\
\hline Gày $(<18,5)$ & 3 & 3,4 \\
\hline Bình thường $(18,5-22,9)$ & 27 & 31,1 \\
\hline Thừa cân $(23-24,9)$ & 57 & 65,5 \\
\hline TB \pm SD & \multicolumn{2}{|c|}{$23,69 \pm 2,70$} \\
\hline
\end{tabular}

Nhận xét: Nhóm thừa cân, béo phì chiếm tì lệ cao nhất $(65,5 \%)$. Nhóm có BMI bình thường chiếm $31,1 \%$ và nhóm bệnh nhân gày chiếm tỉ lệ $3,4 \%$.

1.4 Tình trạng Microalbumin niệu của đôi tượng nghiên cứu

Bảng 3. Tỉ lệ có Microalbumin niệu trong nghiên cứu $(n=87)$

\begin{tabular}{|c|c|c|c|}
\hline Tỉ lệ MAU & $\mathbf{n}$ & $\mathbf{\%}$ & $\overline{\boldsymbol{x}} \mathbf{\pm S D}$ \\
\hline Không có MAU & 60 & 69 & $9,13 \pm 0,29$ \\
\hline Có MAU & 27 & 31 & $59,17 \pm 11,54$ \\
\hline Tống & $\mathbf{8 7}$ & $\mathbf{1 0 0}$ & $\mathbf{5 5 , 7 3 \pm 1 1 , 4 4}$ \\
\hline
\end{tabular}

Nhân xét: Tỉ lệ bênh nhân có Microalbumin niệu là $31 \%$, nhóm không cóMicroalbumin niệu chiếm $69 \%$.

\section{5 Đăc điểm BVMĐTÐ}

Bảng 4. Đăc điểm BVMĐTĐ ( $n=87)$

\begin{tabular}{|c|c|c|}
\hline BVMĐTÐ & $\mathbf{n}$ & $\mathbf{\%}$ \\
\hline Không có tốn thương & 55 & $63,2 \%$ \\
\hline Có tốn thương & 32 & 36,8 \\
\hline
\end{tabular}

Nhận xét: Tỉ lệ bệnh nhân có tổn thương võng mạc mắt là $36,8 \%$ trong khi bệnh nhân không có tổn thương chiếm 63,2%.

2. Nồng độ $C-$ Peptide và mối liên quan đến biến chứng vi mạch

2.1. Nồng độ $C$ - Peptide lúc đói của nhóm nghiên cứu

Bảng 5. Nồng độ C-Peptide lúc đói của nhóm nghiên cứu $(n=87)$

\begin{tabular}{|c|c|}
\hline & Giá trị \\
\hline $\bar{x}_{ \pm}$C - Peptide (nmol/L) & $0,83 \pm 0,35$ \\
& $(0,21 \div 1,81)$ \\
\hline
\end{tabular}

Nhận xét: Nồng độ $\mathrm{C}$ - Peptide lúc đói trung bình của nhóm đối tượng nghiên cứu là $0,83 \pm$ 0,35 , với nồng độ $C$ - Peptide thấp nhất là 0,21 , cao nhất là 1,81.

2.2. Môí tương quan giữa nồng độ $C$ Peptide với MAU

Bảng 6. Mối tương quan giữa nồng độ $C$ - Peptide với MAU (n =87)

\begin{tabular}{|c|c|c|c|}
\hline \multirow[b]{2}{*}{ Đặc điểm } & \multicolumn{2}{|c|}{ Microalbumin niệu } & \multirow[b]{2}{*}{$\mathbf{p}$} \\
\hline & $\begin{array}{c}\text { Không } \\
(n=60)\end{array}$ & $\begin{array}{c}\text { Có } \\
(n=27)\end{array}$ & \\
\hline $\begin{array}{c}\text { C - Peptide } \\
\text { (nmol/L) } \\
\bar{X}_{ \pm} \text {SD }\end{array}$ & $\begin{array}{c}0,88 \pm \\
0,35\end{array}$ & $\begin{array}{c}0,72 \pm \\
0,34\end{array}$ & 0,047 \\
\hline
\end{tabular}

Nhận xét: Trong nhóm đối tượng nghiên cứu, nhóm có Microalbumin niệu có nồng độ $\mathrm{C}$ Peptide $(0,72 \pm 0,34)$ thấp hớn nhóm không có Microalbumin niệu $(0,88 \pm 0,35)$. Sự khác biệt có ý nghĩa thống kể với $p<0,05(\mathrm{p}=0,047)$ (Mann - Whitney U Test). Nồng độ $C$ - Peptide có mối tương quan nghịch biến mức độ vừa phải với nồng độ albumin niệu (Spearman Test, $r=$ $0,352, \mathrm{p}=0,001)$.

2.3. Môi tương quan giữa nồng độ C Peptide với BVMĐTÐ

Bảng 7. Môi tương quan giữa nồng độ $C$ - Peptide với BVMĐTÐ

\begin{tabular}{|c|c|c|c|}
\hline \multirow{2}{*}{ Đặc điểm } & \multicolumn{2}{|c|}{ BVMĐTÐ } & \multirow{2}{*}{ p } \\
\cline { 2 - 3 } & Không & Có & \\
\hline C- Peptide & $0,9 \pm$ & $0,72 \pm$ & 0,041 \\
$(\mathrm{nmol} / \mathrm{L})^{X_{ \pm}}$SD & 0,36 & 0,33 & 0,041 \\
\hline
\end{tabular}

Nhân xét: Trong nhóm đối tượng nghiên cứu, nhóm có BVMĐTÐ có nồng độ $C$ - Peptide $(0,72 \pm 0,33)$ thấp hơn nhóm không có BVMĐTĐ $(0,9 \pm 0,36)$. Sự khác biệt có ý nghĩa thống kê với $p<0,05(p=0,041)$ (Mann - Whitney U Test).

\section{BÀN LUẬN}

4.1. Đặc điểm chung của đối tượng nghiên cứu. Trong nghiên cứu của chúng tôi, tuổi của nhóm đối tượng là từ 31 đến 81 tuổi, trong đó nhóm có độ tuổi từ 40 - 60 chiếm $66,7 \%$. Đây là nhóm đối tượng có độ tuổi lao động -lực lượng đáng kể, đóng góp nhiều cho xã hội. Tỷ lệ bệnh cao nhất ở nhóm này cho thấy ĐTÐ là một gánh nặng cho gia đình và xã hội. Tì lệ nam, nữ mắc bệnh ĐTĐ type 2 trong nghiên cứu là xấp xỉ nhau. Nhóm thừa cân béo phì chiếm tỉ lệ cao nhất $(65,5 \%)$. Tỉ lệ bệnh nhân có Microalbumin niệu là $31 \%$, nhóm còn lại không có Microalbumin niệu chiếm $69 \%$. Kết quả này của chúng tôi cũng khá tương đồng với kết quả của Tauseef Ahmad và cộng sự. ${ }^{2}$ Chúng tôi cũng đánh giá tỉ lệ các bệnh nhân có bệnh võng mạc đái tháo đường (BVMĐTĐ): 36,8\%, nhóm bệnh nhân không có tổn thương chiếm $63,2 \%$. Kết quả này của chúng tôi cũng khá tương đồng với nghiên cứu của Joanne W Y Yau và cộng sự ${ }^{3}$. Có thể thấy BVMĐTĐ đang là một thách thức với các nhà chuyên môn, nếu không được kiểm soát thường xuyên, nó sẽ trở thành một yếu tố chính gây mất thị lực ở người trưởng thành.

4.2. Nồng độ $C$ - Peptide và mối liên quan đến biến chứng vi mạch. Trong nhóm nghiên cứu của chúng tôi, nồng độ $C$ - Peptide lúc đói trung bình của bệnh nhân là $0,83 \pm 0,35$ $\mathrm{nmol} / \mathrm{l}$, với nồng độ thấp nhất là $0,21 \mathrm{nmol} / \mathrm{l}$ và cao nhất là $1,81 \mathrm{nmol} / \mathrm{l}$. Kết quả này của chúng 
tôi cũng khá tương đồng với M.N.Chowta và cộng sự. ${ }^{4}$ Trong nghiên cứu của chúng tôi, nồng độ $\mathrm{C}$ - Peptide lúc đói ở nhóm bệnh nhân có MAU và không có MAU lần lượt là: $0,72 \pm 0,34$ $\mathrm{nmol} / \mathrm{l}$ và $0,88 \pm 0,35 \mathrm{nmol} / \mathrm{l}$. Sự khác biệt có ý nghĩa thống kê với $p<0,05$ ( $p=0,047$, Mann Whitney U Test). Ngoài ra chúng tôi cũng nhận thấy có sự tương quan nghịch biến mức độ vừa phải giữa nồng độ $C$ - Peptide lúc đói với nồng độ albumin niệu (Spearman Test, $r=-0,352, p=$ $0,001)$. Kết quả này cũng tương tự với nghiên cứu của Maimoona Mushtaq Masoom và công sự ${ }^{5}$ cũng như'S. Bo và cộng sự. . Cơ chế về $C-$ Peptide tác động đến chức năng thận vẫn còn chưa được làm rõ. Tuy nhiên có thể C - Peptide có ảnh hưởng đến việc giảm albumin niệu, dựa trên nghiên cứu của Mats Sjoquist và cộng sự thí nghiệm trên chuột. ${ }^{7}$ Cũng trong nghiên cứu của chúng tôi, nồng độ $C$ - Peptide lúc đói trên nhóm bệnh nhân có $B V M Đ T Đ$ và không có $B V M Đ T Đ$ lần Iượt là: $0,72 \pm 0,33 \mathrm{nmol} / \mathrm{lvà} 0,9 \pm 0,36 \mathrm{nmol} / \mathrm{l}$. Sự khác biệt này có ý nghĩa thống kê với $\mathrm{p}<$ 0,05 ( $p=0,041$, Mann - Whitney U Test). Điều này phù hợp với nhận xét của S.Bo và cộng sự̆.

\section{KẾT LUÂN}

- Nồng độ $C$ - Peptide lúc đói trên nhóm bệnh nhân nghiên cứu là $0,83 \pm 0,35 \mathrm{nmol} / \mathrm{l}$.

- Có mối tương quan nghịch biến mức độ vừa phải giữa nồng độ $\mathrm{C}-$ Peptide lúc đói với nồng độ Albumin niệu. Nhóm bệnh nhân có MAU có nồng độ $\mathrm{C}$ - Peptide thấp hơn so với nhóm bệnh nhân không có MAU. Sự khác biệt có ý nghĩa thống kê.

- Nồng độ $C$ - Peptide lúc đói giảm liên quan có ý nghĩa tới BVMĐTĐ.

\section{TÀI LIÊU THAM KHẢO}

1. Gross JL, de Azevedo MJ, Silveiro SP, Canani LH, Caramori ML, Zelmanovitz T. Diabetic nephropathy: diagnosis, prevention, and treatment. Diabetes Care. 2005;28(1):164-176. doi:10.2337/diacare.28.1.164

2. Ahmad $T$, Ulhaq $I$, Mawani $M$, Islam $N$. Microalbuminuria in Type-2 Diabetes Mellitus; the tip of iceberg of diabetic complications. Pak J Med Sci. 2017;33(3):519-523. doi:10.12669/ pjms.333.12537

3. Yau JWY, Rogers SL, Kawasaki R, et al. Global prevalence and major risk factors of diabetic retinopathy. Diabetes Care. 2012;35(3):556-564. doi:10.2337/dc11-1909

4. Chowta MN, Adhikari PM, Chowta NK Shenoy AK, D'Souza S. Serum C peptide level and renal function in diabetes mellitus. Indian J Nephrol. 2010;20(1):25-28. doi:10.4103/09714065.62093

5. Masoom MM, Albiladi F. C-Peptide as a Marker for Diabetic Nephropathy. Intern Med Open Access. 2017; 07(03). doi:10.4172/2165-8048. 1000245

6. Bo $S$, Cavallo-Perin $P$, Gentile $L$, Repetti $E$, Pagano G. Relationship of residual beta-cell function, metabolic control and chronic complications in type 2 diabetes mellitus. Acta Diabetol. 2000;37(3):125-129. doi:10.1007/s005920070014

7. Sjöquist $M$, Huang $\mathbf{W}$, Johansson BL. Effects of C-peptide on renal function at the early stage of experimental diabetes. Kidney Int. 1998; 54(3): 758-764. doi:10.1046/j.1523-1755.1998.00074.x

\section{SO SÁNH CÁC PHƯƠNG PHÁP KIỂM TRA DELTA CHO MộT SỐ XÉT NGHIÊM HÓA SINH}

\section{TÓM TĂT}

Kiểm tra delta (Delta check) là phương pháp kiểm soát chất lượng so sánh kết quả xét nghiệm hiện tai và kết quả trước đây của cùng môt bệnh nhân phát hiện xem sự khác biệt giữa hai kết quả có vượt quá các tiêu chí được xác đinh trước hay không. Kiểm tra delta đảm bảo phát hiện các lỗi giai đoan trước xét nghiệm, lỗi sao chép và lỗi ngẫu nhiên khống thể phát

${ }^{1}$ Trường Đại học Y Hà Nội

${ }^{2}$ Bênh viên Thanh Nhàn Hà Nôi

Chịu trách nhiệm chính: Nguyễn Thị Tùy Châu

Email: anhchau2016hs@gmail.com

Ngày nhận bài: 22.6.2021

Ngày phản biên khoa hoc: 16.8.2021

Ngày duyệt bài: 24.8.2021

\section{Trần Thị Chi Mai ${ }^{1}$, Nguyễn Thị Tùy Châu $^{2}$}

hiên được bằng các phương pháp kiểm soát chất lượng thường được sử dụng, do đó cải thiện độ tin cậy của các xét nghiệm. Nghiên cứu được tiến hành nhằm so sánh phân bố số liệu của khác biệt delta và thay đổi phần trăm delta chó một số xét nghiếm hoá sinh trên bệnh nhân nội trú và ngoại trú. Thu thập các căp kết quả xét nghiệm của bệnh nhân được tiến hành trên cùng một máy hóa sinh tự động. Phân bố khác biệt delta ở các mức phân vị trền bềnh nhân nội trú của xét nghiệm Glucose, AST, ALT, Natri, Kali, Clo, Canxi lớn hơn so với trên bệnh nhân ngoại trú. Với xét nghiệm Urê và Creatinin, phân bố khác biệt delta trên bệnh nhân nội và ngoại trú có xu hướng tương tự nhau. Khi so sánh với bênh nhân nôi trú, phân vị thứ $50,95,97.5$ và 99 của thay đổi phần trăm delta của các xét nghiêm urê, creatinin, glucose, canxi trên bệnh nhân ngoại trú nhỏ hơn; trong khi AST, ALT, 